\title{
A look beyond color: a multi-analytical approach to the study of the frescoes from "Porta Mediana" A41 mausoleum (Cuma necropolis- Italy)
}

\author{
Claudia Di Benedetto (1), Fabio Sossio Graziano (2), Concetta Rispoli (1), Alberto De Bonis (1), \\ Priscilla Munzi (3), Piergiulio Cappelletti (1, 4) \& Vincenzo Morra (1)
}

(1) DiSTAR - Dipartimento di Scienze della Terra, dell'Ambiente e delle Risorse - Università di Napoli Federico II, Via Cintia, 26 - 80126 , Napoli. Tel: 0812538195

(2) Dipartimento di Farmacia - Università di Napoli Federico II, Via D. Montesano, 49 - 80131, Napoli, Italy

(3) Centre Jean Bérard, USR 3133 CNRS - École française de Rome, Via Francesco Crispi, 86 - 80121, Napoli, Italy

(4) Centro Musei delle Scienze Fisiche e Naturali - Università di Napoli FEDERICO II, via Mezzocannone, 8 -80134, Napoli, Italy

Corresponding author e-mail: claudia.dibenedetto@unina.it

Document type: Short note.

Manuscript received 14 November 2019; 28 February 2020; editorial responsibility and handling by R. Cirrincione

\section{ABSTRACT}

This research is part of the PON (Programma Operativo Nazionale) SINAPSIS (SIstema NAzionale Protezione SIti Sensibili), an interdisciplinary project combining archaeological and archaeometric methods.

This paper focuses on frescoes from one of the 70 funeral monuments belonging to "Porta Mediana" Necropolis, a very interesting archaeological context located in Cuma, dating back to the first half of the 3rd century BCE. The study provided detailed information on pigments and colors acquired both on untreated and treated (restored) frescoes

Portable colorimetry and chemical-mineralogical (Raman spectroscopy and X-ray powder diffraction - XRPD, respectively) analyses were performed in situ and on collected samples in order to: 1) identify pigments, raw materials and provenance, 2) point out possiblecolor changes caused by conservative treatments and/or weathering.

The identified palette is typical of the Roman period; it includes both single and mixtures of two or more pigments to obtain particular hues. Moreover, the identified raw materials, such as red and yellow ochres, green frit and Egyptian blue, clearly highlighted the choice to use raw materials from local sources. The use of expensive coloring materials also suggests that the mausoleum belonged to a family or a group of people with a high social status.

KEYWORDS: Cuma, roman pigments, colorimetry, XRPD, SSRRS.

\section{INTRODUCTION}

The study of pigments used in Roman frescoes can provide useful information about the technical knowledge learned since ancient time (Fermo et al., 2013). Starting from the precious contribution of two ancient books, De Architectura by Vitruvius (before the Augustan age) and the Pliny's Naturalis Historia (first century AD), the modern knowledge took advantage, above all, from the geological approach; mineralogical investigations contribute to define the palette of pigments available on local and regional scales and to understand and define the production technology. Moreover, information about nature and provenance of pigments supports archaeological investigations giving a higher value to the site, also allowing to hypothesize trade and exchange routes (Mazzocchin et al., 2004).
However, pigments analysis can represent a big challenge for two main reasons: i) complexity of the material, often characterized by a multi-component mixture ii) limited availability of the material for the sampling (Burgio et al., 2001). The latter issue can be partially overcome by means of non-destructive investigation techniques, such as Raman spectroscopy. In the study of frescoes, along with the nature of pigments, color is also an essential issue, representing the visual appearance of pigments, very important especially when restoration has to be planned. Both pigment and color data are useful to provide precise instructions for urgent actions and make replica of the originals for complete or partial replacement. This study focuses on frescoes from a 'tomb house', identified as A41, (Brun \& Munzi, 2010) belonging to the "Porta Mediana Necropolis" complex (Fig. 1) located outside the urban perimeter, northern side of the ancient town of Cuma in the Campania region of Italy, a settlement founded in $740 \mathrm{BC}$ and representing the oldest Greek colony of the Western Mediterranean Sea. The funerary complex consists of 70 funerary buildings, dated from the 4th century BC to the $3^{\text {th }}$ century $\mathrm{AD}$, excavated by archeologists of the Centre Jean Berard, since 2001 (Brun \& Munzi, 2008).

Despite several studies on potteries (Botti et al., 2006; Grifa et al., 2009; Morra et al., 2013; De Bonis et al., 2018; Germinario et al., 2019) along with those on geomaterials (Graziano et al., 2018) and mortars (Di Benedetto et al., 2018) in this site are available so far, no study has been published on pigments. This research aims to fill this gap reporting the results of analyses carried out either in situ or ex situ. The in situ analyses were performed on restored paintings, while original painting were investigated ex situ.

This allowed to: i) compare results obtained by means of XRPD (X-ray powder diffraction) and Raman analyses from original pigments, ii) perform colorimetric measurements both on treated and untreated samples in order to assess any color change. 


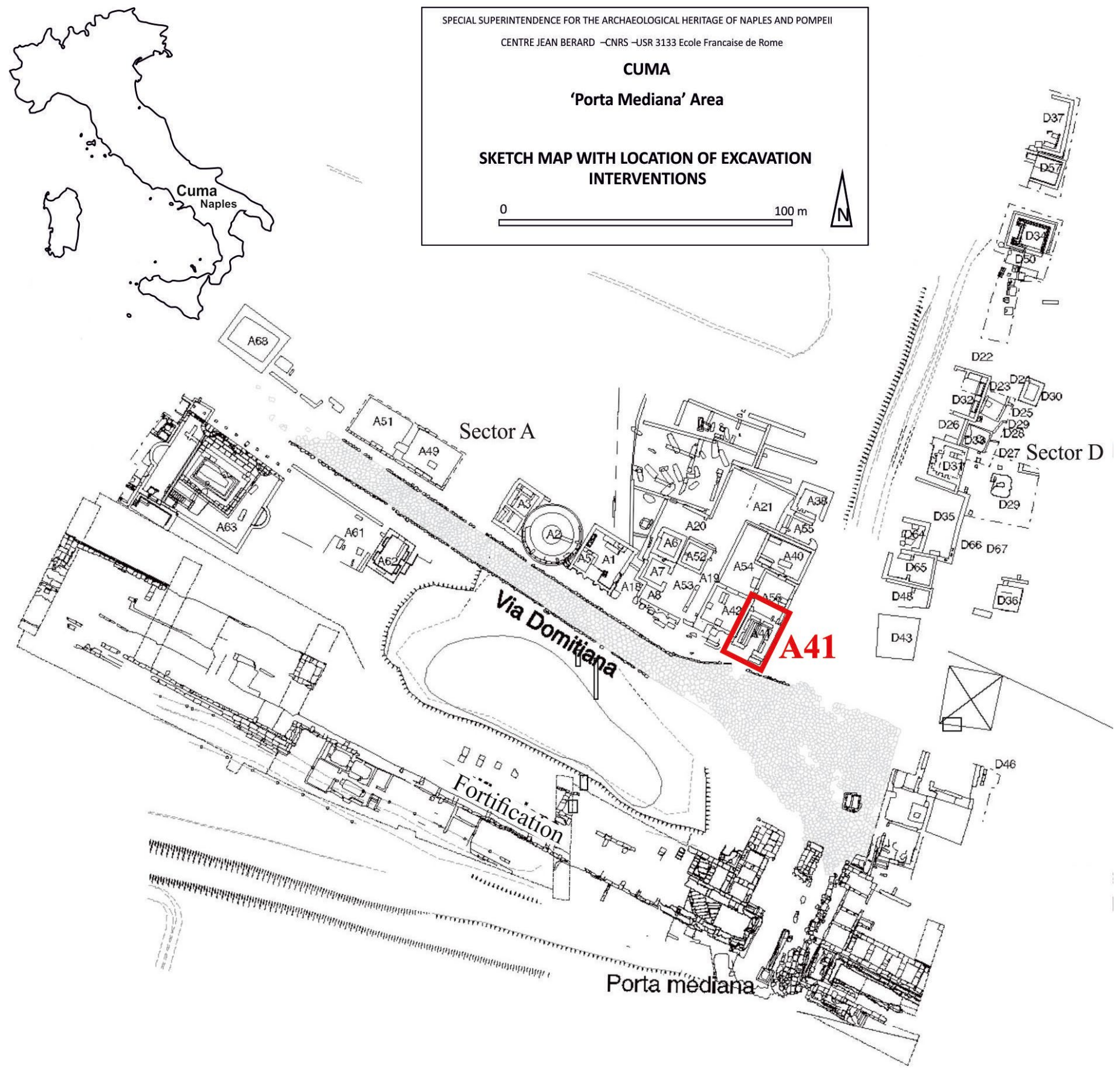

Fig. 1 - Sketch map of the "Porta Mediana" Necropolis (modified after Brun \& Munzi, 2011) which includes the investigated A41 funerary monument (red marked).

\section{A41 MAUSOLEUM}

Classified as "tomb house", the A41 mausoleum was made with opus vittatum - except for the south and east side, made with opus testaceum with red triangular brick - plastered and arranged to placed inhumation burials (Neyme et al., 2017; Munzi et al., 2019; Fig. 2). It is located along the two main road axes, Via Domitiana and the road to Capua, and was built on an earlier funerary building with opus reticolatum dating back to the 1 st century AD.
It is internally divided into six semicircular arcosolia, arranged in pairs, along three walls and richly decorated with paintings. At the bottom of each arcosolia a flower decoration, with red roses, buds and orange flowers with green stems can be observed; it could refer to the feast of roses, a minor recurrence, linked to the memory of the dead, or evocation of Elysium (Brun \& Munzi, 2010). In the lunettes, themes have a symbolic meaning; various scenes were reported: waterfowls, symbols of the souls, peacocks and other birds, or Nereids on sea monsters; the latter accompanying souls of the righteous toward the 


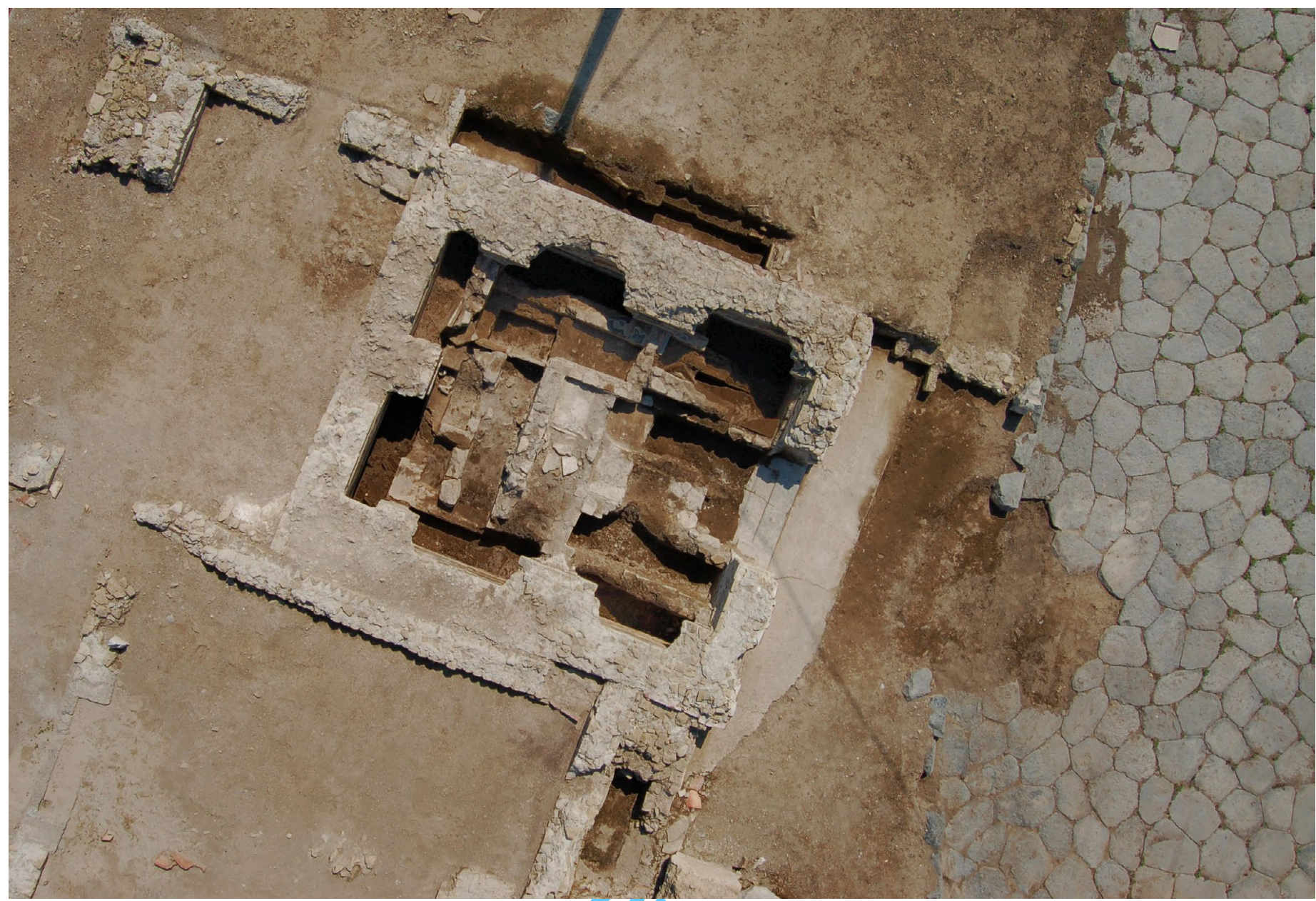

Fig. 2 - Aerial view of A41 mausoleum (Brun \& Munzi, 2011).

islands of the Blessed (Fig. 3 a,b,c; Brun \& Munzi, 2010).

These themes are often represented on the sarcophagi of the second and third centuries, but rarely on paintings of funerary monuments.

The arcosolia, placed in the wall opposite to the entrance, show two scenes with peacocks, symbol of immortality, which were frequently represented starting from $2^{\text {nd }}$ century AD. The pillars among arcosolia show two male figures with mantle, interpretable as genii. The genius is the personification of the rational part of the human soul which, after death, abandons the body to rise in the atmosphere where he continues his life.

The architectural and decorative features of the A41 mausoleum date back to the Severian age (building during first half of the 3rd century AD; Brun \& Munzi, 2010).

In a time range from the end of 3rd century and the beginning of the 4th century $\mathrm{AD}$ the mausoleum was reused with the addition of new burials. In the first period, an adult was placed in the central part of the tomb, many others followed, progressively occupying others parts of the funerary building.

Furthermore, the need of new burials also involved five of the six arcosolia. Recesses, which were executed in the painted plaster for the large coverage tiles, are still visible.. Unfortunately, also in this case the burials were violated by clandestine diggers.

\section{MATERIALS AND METHODS}

Analytical investigations included quantitative, portable, colorimetry, Raman spectroscopy (on both in situ, restored, and original) and XRPD on original frescoes collected before restoration.

Colorimetry is a non-destructive technique based on instrumental reflection measurements in the visible range. Measurement were performed by means of a Konica Minolta CR-400 colorimeter with a diameter of a circular investigated area of $8 \mathrm{~mm}$, a silicon photocell, and a diffused lighting system $\left(0^{\circ}\right.$ view angle, $10^{\circ}$ observer, C illuminator). As color space, $\mathrm{L}^{*} \mathrm{a} * \mathrm{~b}$ (CIE - Commission Internationale de l'Eclairage for International Commission on Illumination, 1976) coordinates were used, where $L^{*}$ represents lightness and ranges from black (0) to white (100), $a *$ and $b *$ the color components $(a *$ from green to red, $\mathrm{b} *$ from blue to yellow).

Difference between restored frescoes and original ones $\left(\Delta \mathrm{E}^{*}\right)$ was also measured according to the equation: $\Delta \mathrm{E}^{*}=\left(\left(\Delta \mathrm{L}^{*}\right)^{2}+\left(\Delta \mathrm{a}^{*}\right)^{2}+\left(\Delta \mathrm{b}^{*}\right)^{2}\right)^{1 / 2}$ (Bianchetti et al., 2000).

Measurements were carried out following the UNI EN 15886:2010 recommendation, on seventy-eight points, in situ, and on 16 samples from original wall painting, under laboratory conditions. Each result derived from the average of at least three measurements performed on each point. 

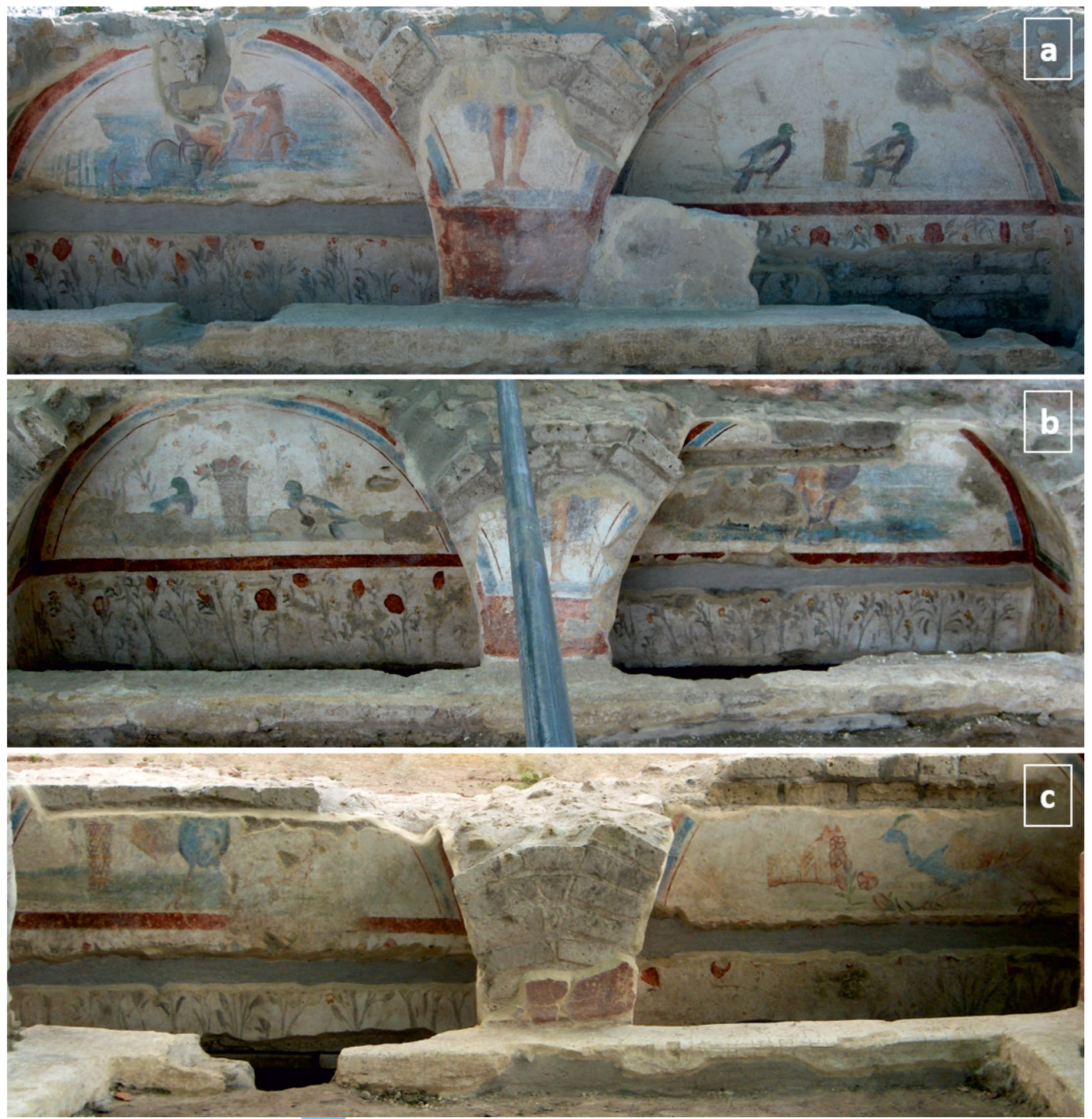

Fig. 3 - Frescoed arcosolia and pillars of A41 mausoleum: a) eastern side b) western side c) northern side. Archive photos from CJB Archive, CNRS-EFR

Raman spectroscopy (SSR-RS) is a quick, noninvasive and non-destructive technique for discrimination of inorganic and organic compounds. The analyses were carried out on collected samples, using a Bruker Bravo Handheld Raman spectrometer, equipped with a Duo Laser excitation ranging from 700 to $1100 \mathrm{~nm}$ during the acquisition, and in Sequentially Shifted Excitation configuration technique (SSETM) for fluorescence mitigation, equipped with a charge-coupled device detector
(CCD). An automatic measurement time was used, in order to avoid saturation of the CCD. The Raman spectra were recorded in the spectral range between 1400 and $250 \mathrm{~cm}-1$ and were processed for baseline correction and smoothing with the Bruker Opus 7.2 software. Raman spectra for the blue and green pigments are not available, as the high fluorescence obscured their diagnostic bands.

In order to unequivocally identify the nature of the pigments, spectra acquired by Raman were compared 
TAB. 1

CIE L*a*b* color coordinates (average values) and $\Delta \mathrm{E}^{*}$ of both in situ (treated) and untreated frescoes from collected samples.

\begin{tabular}{|c|c|c|c|c|c|c|c|}
\hline \multirow{3}{*}{ Color } & \multicolumn{7}{|c|}{ Average values } \\
\hline & \multicolumn{2}{|c|}{$L^{*}$} & \multicolumn{2}{|c|}{$a^{*}$} & \multirow{2}{*}{\multicolumn{2}{|c|}{$\mathrm{b}^{*} \longrightarrow$}} & \multirow[t]{2}{*}{$\Delta \mathrm{E}^{*}$} \\
\hline & untreated & treated & untreated & treated & & & \\
\hline Blue & 65.2 & 62.26 & -3.16 & -2.88 & 2.08 & 1.33 & 3.04 \\
\hline Red & 71.71 & 68.77 & 12.66 & 11.49 & 13.90 & 13.57 & 3.18 \\
\hline Green & 67.53 & 56.43 & -2.2 & -5.52 & 6.59 & 10.47 & 12.21 \\
\hline Yellow & 68.23 & 74.97 & 7.88 & 2.52 & 25.88 & 18.33 & 11.45 \\
\hline
\end{tabular}

to those acquired by XRPD. X-ray powder diffraction (XRPD) is a destructive investigation, performed by a Bruker D2 diffractometer, $\mathrm{CuK} \alpha$ radiation, $30 \mathrm{kV}, 10 \mathrm{~mA}$, $3-70^{\circ} 2 \theta$ scanning interval, $0.017^{\circ}$ equivalent step size, $264 \mathrm{sec}$ equivalent counting time, used to identify mineral pigments (DiSTAR lab., University of Naples Federico II). Painting coatings were removed from the substrate with a chisel and then grinded by hand in an agate mortar to obtain required powders (less than $1 \mathrm{~g}$ ).

\section{RESULTS AND DISCUSSION}

Color changes are the result of both weathering and restoration. Tab 1 shows the $\mathrm{CIE}\left(\mathrm{L}^{*} \mathrm{a} \mathrm{b}^{*}\right)$ color coordinates of untreated and treated wall painting.

The color evaluation was performed by plotting a* versus $b^{*}$ coordinates in the plane, since the $L^{*}$ value depends on several factors, mainly related to used techniques, such as interaction between pigments and binder, time and execution methods (Aldrovandi et al., $2010)$. Variation of color saturation coordinates $\left(a^{*}, b^{*}\right)$ is shown in Figure 4.

Green and blue colors show negative value for $\mathrm{a}^{*}$ and positive for $\mathrm{b}^{*}$, with a general shift to green and yellow respectively. As expected, all red and yellow colors show positive values of both $a^{*}$ and $b^{*}$. The average $a^{*}$ values for treated pigments, except blue, are lower than untreated ones, with major differences for green and yellow ones, compared to red ones.

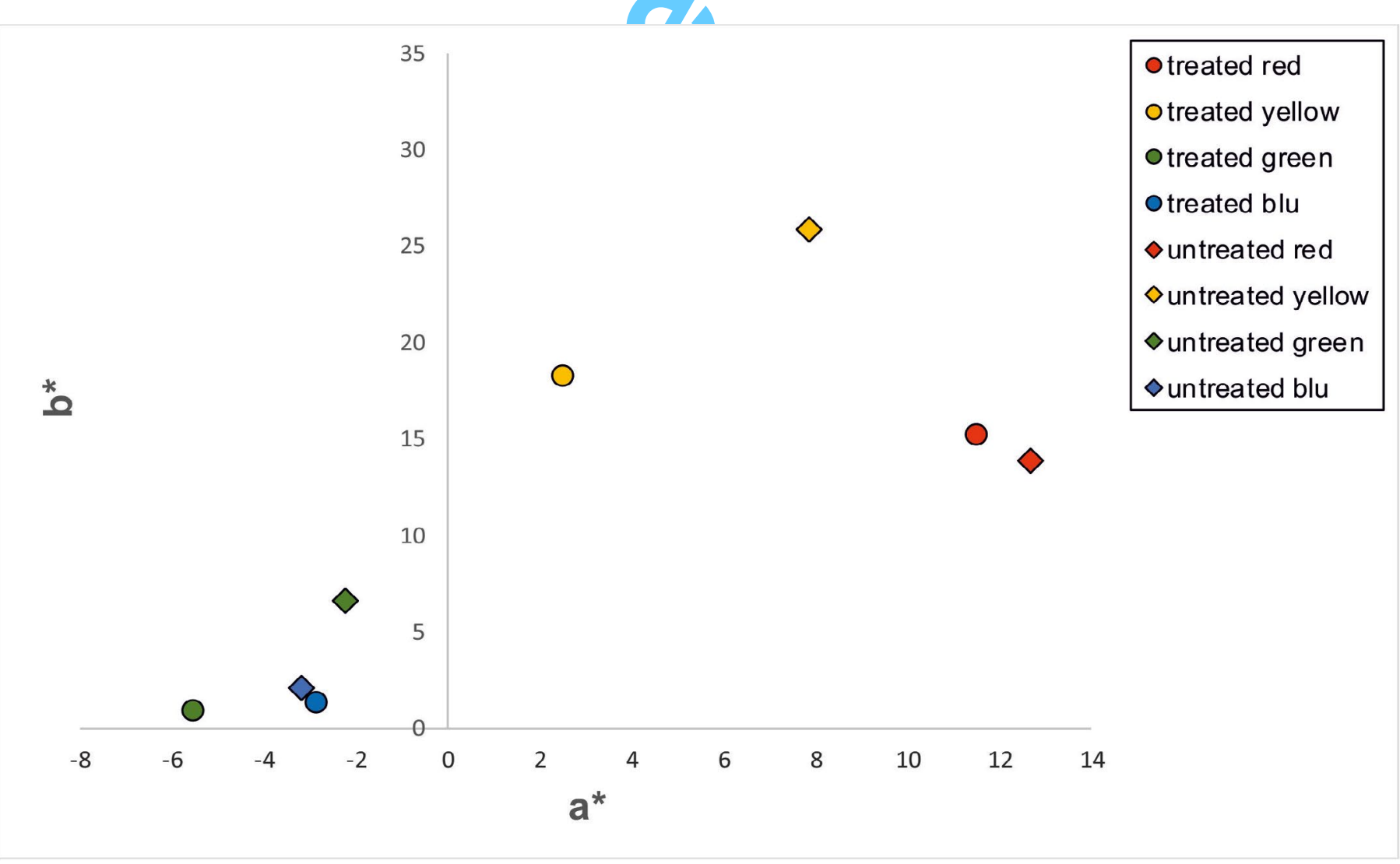

Fig. 4 - Plot of average color coordinates ( $\left.\mathrm{a}^{*}, \mathrm{~b}^{*}\right)$ of untreated samples (diamonds) and in situ treated-restored frescoes (circles). 
Regarding $b^{*}$ color coordinates, green, blue and yellow treated pigments show lower values than the untreated ones, unlike red that shows a higher value of such coordinate .

It is worth to note that the abovementioned differences in $a^{*}$ and $b^{*}$ values recorded by portable colorimetry are often undistinguishable by visual comparisons. Finally, the $\Delta \mathrm{E}^{*}$ total colour difference (Tab. 1), calculated as difference between the average values of treated and untreated colours, ranged from 12.213 of green to 3.180 of red. The results denoted the most relevant difference occurred for green and yellow colour (11.451) with respect to blue and red, which show lower $\Delta \mathrm{E}^{*}$ values (5.864 and 3.183, respectively). This evidence suggests that the treatment used to restore frescoes has a greater influence on the shades of yellow and green, however, actually this hypothesis would require further studies to investigate this behavior.

Mineralogical analyses showed that the used pigments palette is composed by a rich variety of hues, as already recognized in other roman wall painting (Fermo et al., 2013).

As regards mineralogy of the pigments results obtained by XRPD and SSR-RS are reported in Tab. 2.

The two techniques, performed on collected samples, provided the same results in terms of minerals used in pigments.

XRPD spectra were characterized by the ubiquitous presence of calcite peaks (Figg. 5a, 6a, 7, 8; Tab. 2). Therefore, although underlying plaster shows calcium carbonate (calcite) as the only binder,the absence of stratigraphic investigations does not allow the application technique to be established (buon fresco or lime paint; Piovesan et al., 2012). Amourphous phase is also clearly recognizable in all investigated spectra.

For red and yellow colours, an extensive use of ochre has been recognized. They are naturally occurring pigments whose colour is given by the different degree of hydration of the iron oxide contained therein (Selim, 1967; Fermo et al., 2013). In the investigated A41 mausoleum,

TABLE 2

Mineral pigments identified by XRPD and Raman spectroscopy.

\begin{tabular}{|l|l|l|}
\hline Colour & XRPD & Raman \\
\hline Red & hematite, quartz, calcite & hematite, quartz, calcite \\
\hline Yellow & goethite, quartz, calcite & goethite, quartz, calcite \\
\hline Egyptian Blue & cuprorivaite, quartz, calcite, tridymite & - \\
\hline Green frit & cuprorivaite, tridymite, quartz, muscovite, calcite & - \\
\hline
\end{tabular}

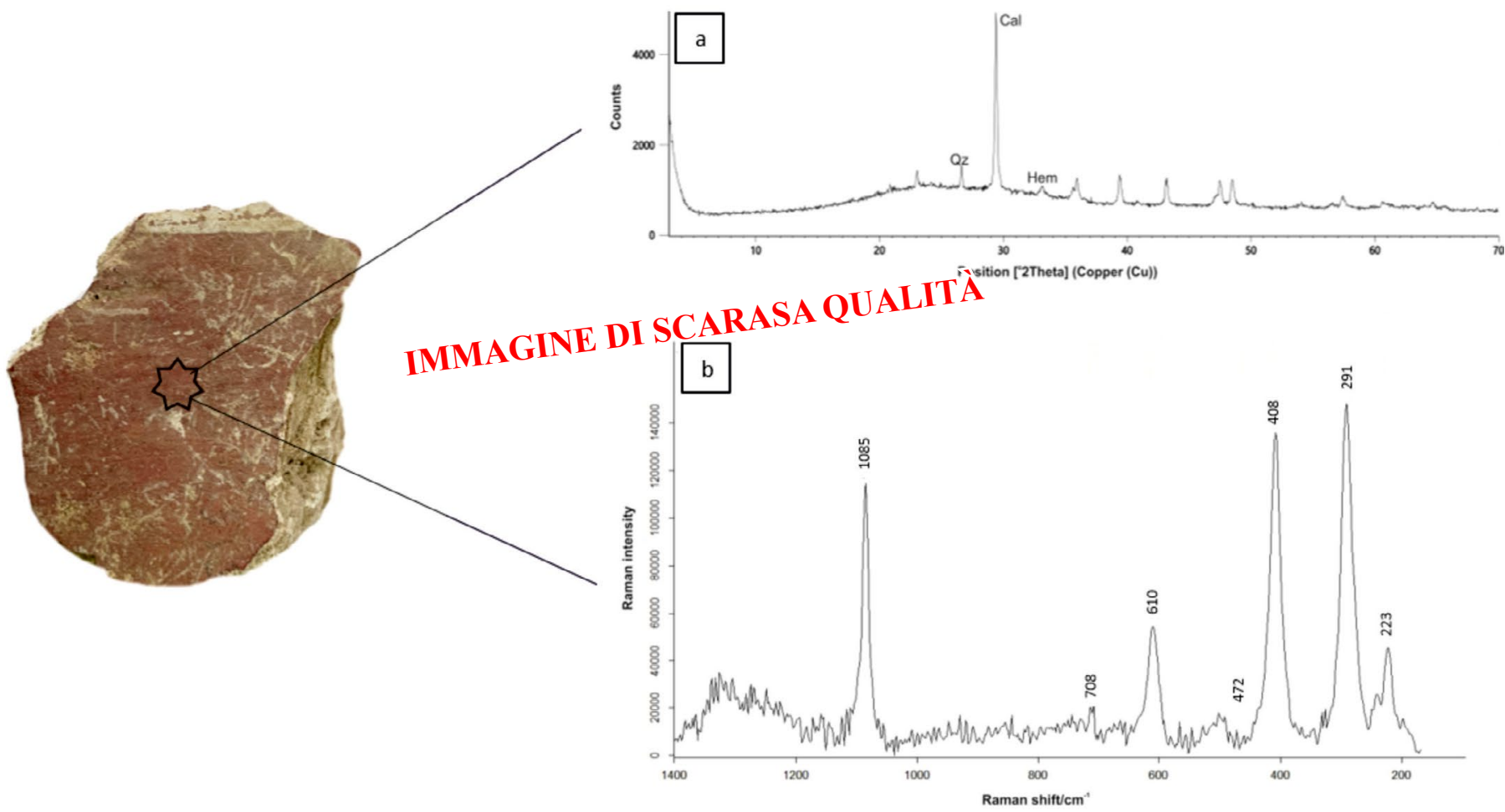

Fig. 5 - XRPD (a) and Raman (b) spectra of red pigment. 


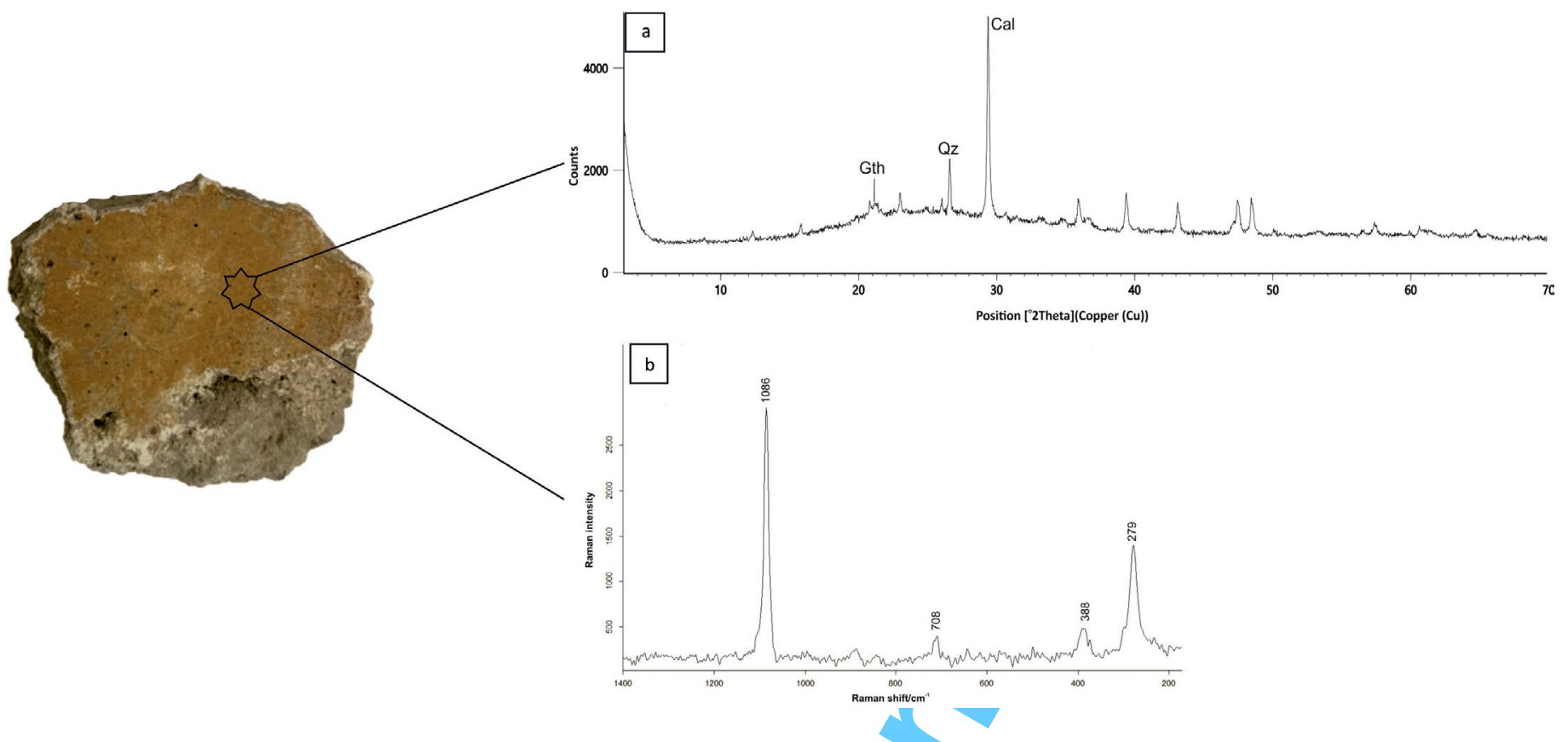

Fig. 6 - XRPD (a) and Raman (b) spectra of yellow pigment.

the red pigment was used for both large surfaces and small designs; the resulting iron oxide is hematite $\left(\alpha-\mathrm{Fe}_{2} \mathrm{O}_{3}\right.$; Selim, 1967; Eastaugh et al., 2008; Fig 3). XRPD analyses show the use of hematite as red pigment along with quartz and calcite (Fig. 5a). The same phases were also identified by Raman, which shows hematite (bands at 223, 291, 408 and $610 \mathrm{~cm}^{-1}$;Fig. 5b), along with that of calcite $\left(1085 \mathrm{~cm}^{-1}\right.$; Fig. 5b - Germinario et al., 2018) deriving from the plaster and quartz (472 and $708 \mathrm{~cm}^{-1}$; Fig. 5b).

Red ochre, known since the prehistoric era, was widely used by Romans due to its availability, as well as inexpensiveness (Avlonitou, 2016). It is worth to highlight, in the area of Puteolis (Pozzuoli, important town near Cuma), the availability of red earth deposits that provided a colouring pigment named Terra di Pozzuoli (Selim, 1967; Eastaugh et al., 2008).

The yellow colour, mainly employed for representing details, was obtained by using the mineral goethite $\left(\mathrm{Fe}_{3}+\mathrm{O}(\mathrm{OH})\right.$ ), shown by XRPD pattern (Fig. 4a), probably obtained from the same red raw material (Pomies et al., 1999). Calcite, from plaster along with quartz was also detected (Fig. 6a).

\section{$(0)$}

Raman spectra (Fig. 6b) confirmed the use of a natural earth as yellow pigment, showing the characteristic band of goethite $\left(388 \mathrm{~cm}^{-1}\right)$. Quartz and calcite bands were also detected at 279 and $1086 \mathrm{~cm}^{-1}$.

As reported by Vitruvius and Pliny the elder, yellow ochre was extensively used in Roman period in wall paintings. It is an earth pigment (ferric hydroxide) with clay impurities, deriving from the direct weathering of iron-rich ore deposits or soils from the underlying bedrocks (Selim, 1967; Eastaugh et al., 2008).

The pigments used to obtain both green and blue hues, were identified exclusively by XRPD, due to strong fluorescence affecting Raman spectra that hindered their acquisition (Germinario et al., 2018).

Regarding green pigment, XRPD spectrum shows characteristic peaks, inferring the presence of cuprorivaite, along with quartz, tridymite and muscovite (Fig. 7; Tab. 2).

The finding of both cuprorivaite and tridymite, suggests the use of an advanced "ceramic technology" namely a sintering process in a furnace with firing temperatures ranging values between 950 and $1150^{\circ} \mathrm{C}$ for the synthesis of the green products, named green frit, the production

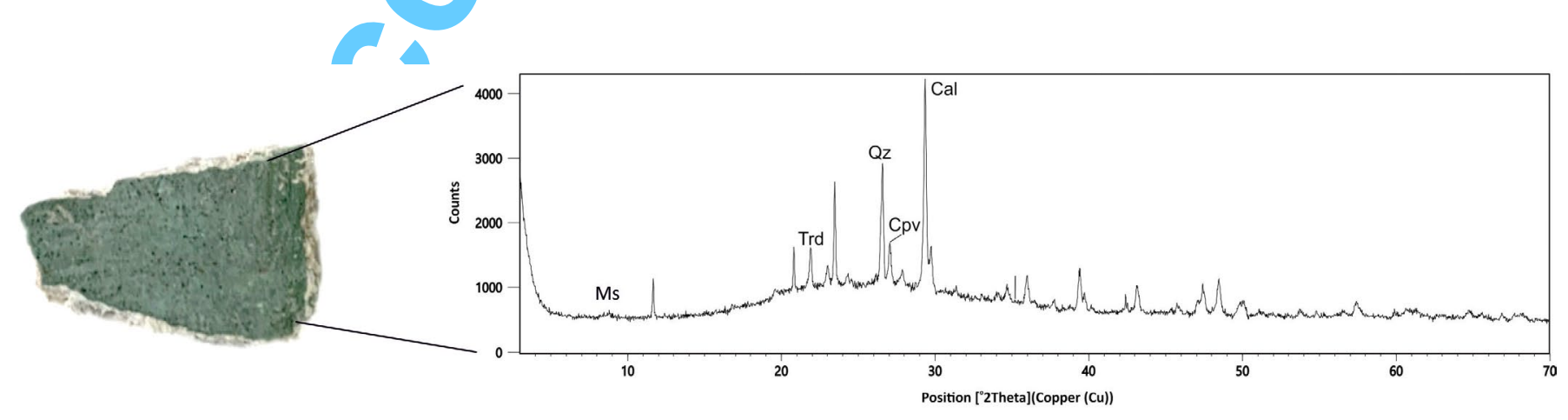

Fig. 7 - XRPD pattern of green sample. 
of which in the investigated area was already ascertained (Grifa et al., 2016).

XRPD spectrum of blue sample pigment showed the presence of cuprorivaite, quartz, calcite and tridymite (Fig. 8; Tab. 2).

The mineralogical composition suggests that the pigment was mainly obtained by using the precious Egyptian blue, a synthetic polycrystalline compound identified as cuprorivaite $\left(\mathrm{CaCuSi}_{4} \mathrm{O}_{10} ; \mathrm{Tab}\right.$. 3), a tetra silicate of calcium and copper (Minguzzi, 1938; Mirti et al., 1995). It was generally obtained by heating silica (feldsparquartz sand) and calcium carbonate (carbonate sand) with a copper alloy (e.g., copper/bronze filings or malachite) and an alkali flux such as natron or soda-rich plants (Selim, 1967; Eastaugh et al., 2008, Grifa et al. 2016).

It represents one of the oldest synthetic pigments in ancient Egyptian history (Laurie et al., 1914; Jaksch et al., 1983), recorded in wall painting since 2900 BC (Caubet, 2007; Hatton et al., 2008). The production technique of Egyptian blue in the area of Cuma was reported in detail in the first century AD by Vitruviusthat in De Architectura treatise provided detailed information about a craftsman (Vestorius), recipe and technology. The pigment, named as coeruleum, derived from firing in a furnace ("due to the vehement heat") small parts of copper, fine sand, and potassium nitrate (salnitro), previously ground and moistened (Fermo et al., 2013). Vitruvius also identified the area of production of the pigment in Puteoli , to which can be added Cuma, in the northern sector of Campi Flegrei, where a production was also attested (Grifa et al., 2016).

Blue pigment covers, as thin layer, large surfaces of A41 mausoleum.

\section{CONCLUSIONS}

This study provided new insights about pigments commonly used in Roman age, especially in the area of Cuma.

Investigations were carried out on one of the seventy mausoleums, the so called A41, having some best-preserved examples of colour use, for decorative purposes, in funerary sites.

Both in situ and laboratory colourimetric measurements and mineralogical analyses evidenced some chromatic variations (probably resulting from both natural and conservative processes), allowing to trace the ancient painter's palette and hypothesize manufacturing technologies and the production area. Comparison between original and restored painting evidenced that conservative operations cause colour variations that mainly affect red and yellow pigments.

After restoration, in fact, the yellow pigment shows the strongest variations in both $\mathrm{a}^{*}$ and $\mathrm{b}^{*}$ component shifting towards lower values, evidencing a general shift to green and blue respectively; the same trend was shown by the green colour, although with less differences in the colour coordinates values between treated and untreated. Red colour shows little variations after restoration with an opposite trend for $a^{*}$ (that decreases) and $b^{*}$ (that slightly increases). The blue colour is the less affected by restoration, showing negligible variations in colour coordinates. Regarding visual perceptions of colour change after restoration, the $\Delta \mathrm{E}^{*}$ parameters allowed us to assess the different behavior among pigments: red and blue show no appreciable variations by visual inspection,. Yellow and green result the most affected by restoration treatments, showing colour variations that are highly noticeable, by visual inspection.

Mineralogical information about pigments let us hypothesize the supply area of raw materials; the blue pigment (cuprorivaite) may have been produced by a specific sand (containing quartz + feldspars + carbonates) widely available in the Northern part of Campi Flegrei (Morra et al., 2013; Balassone et al., 2016). This furtherly confirms the existence of other production areas, in addition to that of Pozzuoli, identified in Cuma and Liternum, as reported by Grifa et al. (2016); the same provenance hypothesis can be also followed for the other two most used pigments (hematite for red and goethite for yellow).

Regarding techniques used for the realization of painting, the examined samples were formed from both natural and synthetic pigments, consistent with those mentioned in the two ancient treatises Vitruvius' $D e$ Architectura and Pliny's Naturalis Historia (first century AD) and identified by modern analytical techniques (Bearat et al., 1997; Fermo et al., 2013). Moreover, the occurrence of calcite in each spectrum led us to infer the use of the fresco painting technique, widely used in the Roman period, mainly for its durability.

\section{ACKNOWLEDGMENTS}

This research was granted by national research project PON "SINAPSIS" (Sistema Protezione Siti Sensibili - PON01_01063).
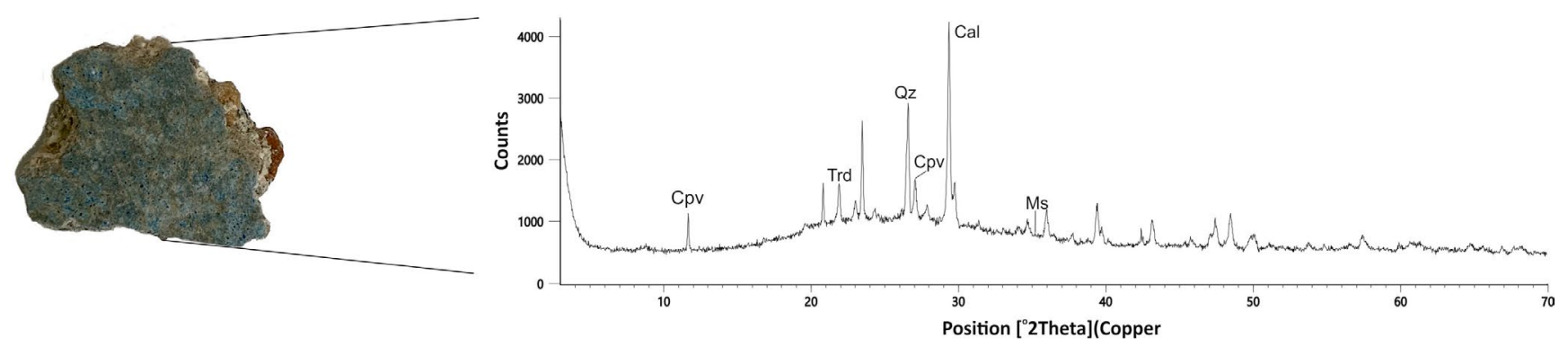

Fig. 8 - XRPD pattern of the blue sample. 
The authors wish to thank the former Soprintendenza archeologica of 'Parco Archeologico di Cuma', for courtesy of Dr Paolo Caputo, that allowed the sampling phase.

\section{REFERENCES}

ALDROVANDI A., CARUSO O \& MARIOTTI P.I. (2010). - Caratterizzazione de materiali pittorici nelle pitture murali mediante tecniche fotografiche. OPD restauro, Centro Di Della Edifimi SRL n. 22 pp. 55-80.

AvLONITOU L. (2016) - Pigments and colours: An inside look at the painted decoration of the Macedonian funerary monuments. J. Archaeol. Science: Reports 7, 688-678. Elsevier.

Balassone G., Aiello G., Barra D., Cappelletti P., De Bonis A., DONADIO C., ET AL. (2016). Effects of anthropogenic activities in a Mediterranean coastland: The case study of the FalernoDomitio littoral in Campania, Tyrrhenian Sea (southern Italy). Marine Pollution Bulletin 112, 271-290. https://doi.org/10.1016/j. marpolbul.2016.08.004

Bearat H., Fuchs M., Maggetti M. \& PaunieR D. (1997) - Roman wall painting. Materials, techniques, analysis and conservation, in Proceedings of the International Workshop on Roman Wall Painting (Institute of Mineralogy and Petrography Fribourg University, Fribourg, 1997)

Bianchetti P, Talarico F., Vigliano M.G. \& Fuad Alib M. (2000) Production and characterization of Egyptian Blue and Egyptian green frit. Journal of Cultural Heritage 1 pp. 179-188.

Botti A., Ricci M.A., De Rossi G., KockelmanN W. \& Sodo, A. (2006) - Methodical aspects of SANS and TOF neutron diffraction measurements on pottery. The case of Miseno and Cuma. J. Archaeol. Sci., 33, 307-319.

BRUN J.-P. \& MunZI P. (2008) - La necropoli romana della Porta Mediana. In F. Zevi, F. Demma, E. Nuzzo, C. Rescigno, C. Valeri (éd.), Museo archeologico dei Campi Flegrei. Catalogo generale. 1. Cuma, Napoli, pp. 396-399.

BRUN J.-P. \& MUNZI P. (2010) - La decorazione pittorica di un mausoleo di età severiana nella necropoli settentrionale di Cuma. In: Irene Bragantini, Atti del X Congresso: Annali di archeologia e storia antica, 499-510.

BRUN J.-P. \& MunzI P. (2011) - Les travaux du Centre Jean Bérard au nord de l'enceinte urbaine et au sud de l'acropole. Bulletin del société française d'archéologie classique, revue archéologique n. 51 pp 150-72. Presses Universitaires de France, Paris, 2011.

Burgio L., MElessanaki K., Doulgeridis K., Clark R.J.H. \& ANGlos D. (2001). Pigment identification in paintings employing laser induced breakdown spectroscopy and Raman microscopy. Spectrochimica Acta Part B 56, 905-913.

Caubet A. (2007) - Faïences et matieres vitreuses de l'Orient ancien; 309 pp. Musee du Louvre_Editions, Paris, France, 2007.

De Bonis A., ARIEnZo I., D'ANTONIO M., Franciosi L., GERMinARIO C. GRIFA C., Guarino V., LANGella A. \& MORRA V. (2018) - Sr$\mathrm{Nd}$ isotopic fingerprinting as a tool for ceramic provenance: its application on raw materials, ceramic replicas and ancient pottery. Journal of Archaeological Science 94. https://doi.org/10.1016/j. jas.2018.04.002

Di Benedetto C., Graziano S.F., Guarino V., Rispoli C., Munzi P. MORRA V. \& CAPPELlETTI P. (2018) - Romans established skills: Mortars from D46b mausoleum, porta mediana necropolis, Cuma (Naples). Mediterranean Archaeology and Archaeometry, 18 (5), pp. 131-146. https://doi.org/10.5281/zenodo.1285895.

Eastaugh N., Walsh V., Chaplin T. \& Siddall R. (2008) - Pigment Compendium: A Dictionary and Optical Microscopy of Historical Pigments. Butterworth-Heinemann-Elsevier.

Fermo P., Piazzalunga A., DE Vos M. \& ANDreoli M., (2013) - A multianalytical approach for the study of the pigments used in the wall paintings from a building complex on the Caelian Hill (Rome). App Phys A v.113 pp. 1109-1119. https://doi.org/10.1007/s00339-0137754-8

JAKSCH H., SEIPEL W., WeINER K.L. \& El GoResy A. (1983) Naturwissenschaften 70: 525. https://doi.org/10.1007/BF00376668

Germinario C., Izzo F., Mercurio M., Langella A., Sali D., KaKoulli I., DE BONIS A., GRIFA C. (2018) - Multi-analytical and non-invasive characterization of the polychromy of wall paintings at the Domus of Octavius Quartio in Pompeii. Eur. Phys. J. Plus (2018) 133: 359. https://doi.org/10.1140/epjp/i2018-12224-6.
Germinario C., Cultrone G., Cavassa L., De Bonis A., izzo F., Langella A., Mercurio M., Morra V., Munzi P., Grifa C. (2019) - Local production and imitations of Late Roman pottery from a well in the Roman necropolis of Cuma in Naples, Italy. Geoarcheology, 34, 62-79. https://doi.org/10.1002/gea.21703

Graziano S.F., Di Benedetto C., Guarino V., Rispoli C., MunZi P., CAPPELLETTI P. \& MORRA V. (2018) - Technology and building materials in Roman age (1st BC - 2nd AD): The 'Mausoleo Della Sfinge' from the archaeological site of Cuma (Italy). Mediterranean Archaeology and Archaeometry, 18 (5), pp. 81-94. https://doi.org/10.5281/zenodo.1256057

Hatton G.D., ShORTLAND A.J. \& TITE M.S. (2008) - The Production Technology of Egyptian Blue and Green Frits from Second Millennium BC Egypt and Mesopotamia, J. Archaeol. Sci., 35 [6] 1591-604 (2008). Archaeometry, 55 [5] 852-79.

Grifa C., Morra V., Langella A. \& Munzi P. (2009) - Byzantine ceramic production from Cuma (Campi Flegrei, Napoli). Archaeometry, 51, 2009, 75-94.

Grifa C., CaVassa L., De Bonis A., Germinario C., Guarino V., IzZO F., KaOKOUlli I., Langella A., Mercurio M. \& Morra V. (2016) - Beyond Vitruvius: New insight in the technology of Egyptian blue and green frits. Journal of the American Ceramic Society, 99, 3467-3475.

Horgnies M., Daroue-Ceretti E., Bayle M., Gueit, E., \& AUCOUTURIER, M. (2014) - An exceptionally perennial surface artwork: fresco on lime or on cement. Surface and Interface Analysis https://doi.org/10.1002/sia.5392

Laurie A.P., MCLintock W. F. P. \& Miles F.D. (1914) - "Egyptian Blue," Proc. Roy. Soc. A. Math. Phys., 89, 418-29.

Mazzocchin G.A., Agnoli F. \& SAlvadori M. (2004) - Analyses of Roman age wall paintings found in Pordenone, Trieste and Montegrotto. Talanta 64 (2004) 732-741, Elsevier.

Minguzzi C. (1938) - Cuprorivaite, un nuovo minerale. Periodico di mineralogia, 8:333-345

Mirti P., APPOlonia L., Casoli A., Ferrari R.P., LaUREnTI E., AMisano CANESI A. \& CHIARI G. (1995) - Spectrochim. Acta 51A (1995) $437-$ 446.

Morra V., De Bonis A., Grifa C., Langella A., Cavassa L. \& Piovesan R. (2013) - Minero-Petrographic Study of Cooking Ware and Pompeian Red Ware (Rosso Pompeiano) from Cuma (Southern Italy). Archaeometry 55, 5, 852-879

MunZi P., Neyme D., PouZAdoux C. \& ChAPELIN G. (2019) - Una tomba monumentale dipinta di epoca severiana a Cuma (Campania, Italia): progetto di conservazione e di valorizzazione. La realizzazione del programma (parte 2), Nuovi dati per la conoscenza della pittura antica. Atti del colloquio AIRPA. Aquileia 16-17 giugno 2017, Roma coll. «Collana AIRPA »1, 2019, p. 239-244.

Neyme D., Munzi P. \& Pouzadoux C. (2017) - Un tombeau peint d'époque sévérienne à Cumes (Campanie, Italie): projet de conservation et de mise en valeur, in J. Boislève, A. Dardenay, Fl. Monier (éds.), Peintures murales et stucs d'époque romaine. Études toichographologiques, Actes du 28e colloque de l'AFPMA Paris, 20-21 novembre 2015, Pictor collection de l'AFPMA 6, Bordeaux 2017, p. 247-253.

Pliny the Elder, Natural History in Ten Volumes, edited by H. Rackham (Loeb Classical Library, Cambridge, 1968).

Piovesan R., Mazzoli C., Maritan L. \& Cornale P. (2012). Fresco and lime-paint: an experimental study and objective criteria for distinguishing between these painting techniques. Archaeometry 54, pp. 723-736.

Pomiès M.P., Menu M. \& Vignaud. C. (1999) - Red Palaeolithic Pigments: Natural Hematite or heated goethite? Archeometry 41, 2, 275-285.

SELIM A. (1967) - I colori pompeiani. De Luca Editore

Toschi F., Colosi F., Lentini A., PALADINI A., 2016. A multidisciplinary study of Roman painted plasters from Roman villa in Ponti Novi (Sabina area, Lazio, Italy). Journal of Archaeological Science: Reports. v. 7, pp. 114-122.

UNI EN 15886 (2010) - Misura del colore delle superfici. Conservazione dei Beni Culturali.

VITRUVIUS M.P.-De Architectura (On Architecture); 499 pp. Harleian Manuscript 2767 and Translated into English, Vol 2 Edited by F Granger (The Loeb classical Library). Heinemann, London, UK, 1962. 